\title{
REPETITION OF COLLOCATION IN THE TALK OF THE TENTH GRADE TEACHER IN SMA NEGERI 11 MEDAN
}

\author{
*Sarah Cindy Cristin Tobing. \\ **Prof. Dr. Sumarsih, M.Pd. \\ **Dr. Meisuri, M.A.
}

\begin{abstract}
Tobing, Sarah Cindy Cristin. Repetition of Collocation in The Talk of The Tenth Grade Teacher in SMA Negeri 11 Medan. English Educational Program, Medan State University, 2020.

The purpose of this study was to analyze the types of collocations that mostly used during the teaching and learing process, the patterns of repetition, and the function of repetition. This research was conducted by using a descriptive qualitative design. The subject of the study was the English teacher of the tenth grade in SMA Negeri 11 Medan. The data were collected by conducting an observation, voice/video recording, and interview. The result of the study showed that lexical collocation oocured dominantly (68\%) and followed by the grammatical collocation (32\%). Lexical collocation of verb + adverb was the type that mostly occured in teacher talk (TT). The teacher also tended to use the pattern of self-reptition to repeat the collocation in the class. Aside from assisting the students to catch meanings, another reason as to why the repetition was implemented in the class was because it helped the teacher to control the class, to give commands to the students, and also to encourage the students.
\end{abstract}

Keywords : Collocation, Repetition, Teacher Talk

*Graduate Status
$* *$ Lecturer Status 


\section{INTRODUCTION}

\section{A. The Background of the Study}

Mastering vocabulary is an essential element to learn English as a foreign language. Students of English are required to understand words in English as it supports the students to communicate and also to improve the English proficiency in listening, speaking, reading, and writing. Learning vocabulary was seen as a key element to achieve a high level of proficiency in language learning by a great number of theoreticians (Boers \& Lindstromberg, 2008; Zu, 2009; Schmitt, 2000). It is though that collocation is one of the most important aspects of knowing word. That is to say, in order to deepen the understanding of a word, students of English must know its collocation (Duan \& Qin 2012). Shin and Nation (2008), also point out that one of the reasons as to why teachers and learners should be interested in collocations is that collocations improve learners' language fluency and ensure native-like selection.

Students learn a lot from the talk that the teacher gives. Teacher talk is influential to the success of a learning process as it is one of the input for students in acquiring language. Bloom points out that we must begin to examine what teachers do, not what teachers are. Therefore, it is worthwhile to look at the treatment of teachers using collocation in their talks. During the teaching and learning process, it helps to overcome cognitive difficulties if teachers insert mother tongue for the certain condition such as to translate difficult words. However, translating their talk from English to Bahasa Indonesia to make the student understand the teachers' intention. This brought ineffectiveness to the learning proccess as the teachers tend to translating which is considered as a waste of time because learners are spending their time in both languages, trying to go from one to the other and not immersing themselves in the language they are learning.

Instead of translating or interpreting the talk, it is believed that repeating is good for the foreign language learners. Basically, repetition means to repeat something that has been said or written; in other words, doing it over and over again. Repetition is the key to successfully achieve the English fluency as it helps students remember something when they learn to speak English. Based on behaviorist's view, learning to speak a foreign language is like the other skills. It is simply a question of correct habit formation. Larson-Freeman (2000; 43) defines language learning is a process of habit formation. The more often something repeated, the stringer the habit and the greater the learning.

Students need to really recognize vocabulary and understand its meaning as it will make them to be confident in using the vocabulary itself. Repetition is very greatly helpful with this case. Repetition strategies are crucial, especially when starting to learn vocabulary The more often a 
vocabulary is repeated, the more the students get familiar with it and understand its meaning.

\section{REVIEW OF LITERATURE}

\section{A. Theoretical of framework}

\section{Vocabulary Mastery}

\section{a. Mastery}

Quirk, (1991: 644) states that mastery is great skill or knowledge in a particular subject or activity. Knowledge is a familiarity with something which may include information, description or skill acquired through experience or education. Knowledge is beneficial to the student to get more information and minimize misunderstanding.

\section{b. Vocabulary}

Vocabulary is the total number of words in a language; all the words known to a person or used in a particular book, subject, etc; a list of words with their meaning (Hornby, 8 1995: 1331).

\section{c. Vocabulary Mastery}

Vocabulary mastery indicates that students are expected to be competent to know words, understand their meaning, and use them properly . The deeper the students master vocabulary, the better they perform a language. The lackness of vocabulary will lead the students to difficulties in mastering language skills.

\section{Collocation}

\section{a. Definition of Collocation}

Collocations are combinations of words that are preferred over other combinations that otherwise appear to be semantically equivalent. For instance, Matthews argues that " toasted" and " roasted" are two different word for same process yet each collocate with different words that can't be replaced, roasted meat and toasted bread (Matthews, 1981) cited from Croft and Cruse (2004: 249).

\section{b. Types of collocation}

In English, as in other languages, there are many fixed, identifiable, non- idiomatic phrases and constructions. Such groups of words are called recurrent combinations, or collocations. Collocations fall into two major groups: grammatical collocations and lexical collocations.

\section{c. Role of Collocation}

Shin and Nation (2008) also explain that one of the reasons as to why teachers and learners should be interested in 
collocations being that collocations improve learners' language fluency and ensure native-like selection.

\section{Teacher Talk (TT)}

The kind of language used by the teacher or instruction in the classroom is known as teacher talk (TT). In this term, Longman Dictionary of Language Teaching and Applied Linguistics defines it as variety of language sometimes used by teachers when they are in the process of teaching. The objectives of teacher's talk is to communicate with students and develops students' foreign language proficiency. In class, teacher talk plays role in conducting instructions, cultivating their intellectual ability and managing classroom activities (Xiao-Yan, 2006).

\section{Repetition}

In the literature on repetitions the most common distinction made in terms of type is the one between repeating what is said by oneself, and repeating what is uttered by another speaker. This distinction appears under different names cited in Silva (2007): same-speaker vs. secondspeaker repetition (Norrick, 1987), self- and allo-repetition (Tannen, 1987), self- and other-repetition (Johnstone et al., Rydland and Aukrust).

\section{III.RESEARCH METHODOLOGY}

Considering the objectives of the problem, the researcher applied the method of descriptive qualitative. Descriptive qualitative refers to the study where the data collected in the form of words or images rather than numbers. The findings of the study are presented by using the data quoted from documents, field notes, and interviews or excerpts from videotapes, audiotapes, or electronic communications are used to present the findings of the study (Bogdan and Biklen, 1982).

\section{RESEARCH FINDINGS AND DISCUSSIONS}

\section{a. Research Findings}

In analysing the data, there were 3 steps conducted by the writer namely (1) Data Condensation; (2) Data Display; (3) Data Drawing/ Verification.

\section{Data Condensation}

The data of this study were taken from the talk of an English teacher who taught in 4 (four) parallel classes of tenth grade in SMA Negeri 11 Medan.

\section{Data Display}


The data was selected from the transcription of teacher talk during the teacher and learning in the classrooms. The selected data will then be identified and written in percentages.

\section{Data Drawing}

Conclusion drawn based on the result which is shown in the data display. Then, the conclusion verified by looking back on the field notes which the researcher has got during observation.

\section{b. Discussion}

\section{The Dominant Types of Collocation Used by The Teacher}

The percentage of collocation that a teacher of SMA Negeri 11 Medan used during the teaching and learning process in the classroom. From 2 (two) major of collocation group, lexical collocation with the percentage $68 \%$ dan 31 (thirty one) collocations is more dominant compared to grammatical collocation with the percentage $32 \%$ and 12 (twelve) collocations. Furthermore, the collocation type of verb + adverb places the highest position as the dominant types of collocation used by English teacher in SMA Negeri 11 Medan.

\begin{tabular}{|c|c|c|c|c|}
\hline $\begin{array}{c}\text { Group of } \\
\text { Collocation }\end{array}$ & $\begin{array}{c}\text { Type of } \\
\text { Collocation }\end{array}$ & Number & Percentage & $\begin{array}{c}\text { Percentage } \\
\text { of each } \\
\text { group of } \\
\text { Collocation }\end{array}$ \\
\hline \multirow{6}{*}{$\begin{array}{c}\text { Grammatical } \\
\text { Collocation }\end{array}$} & $\begin{array}{c}\text { Noun }+ \\
\text { Preposition }\end{array}$ & 2 & $4 \%$ & \multirow{6}{*}{$32 \%$} \\
\hline & $\begin{array}{l}\text { Noun + to- } \\
\text { infinitive }\end{array}$ & 1 & $3 \%$ & \\
\hline & $\begin{array}{c}\text { Preposition }+ \\
\text { Noun }\end{array}$ & 3 & $6 \%$ & \\
\hline & $\begin{array}{l}\text { Adjective + } \\
\text { preposition }\end{array}$ & 5 & $11 \%$ & \\
\hline & $\begin{array}{l}\text { Adjective + to- } \\
\text { infinitive }\end{array}$ & 2 & $4 \%$ & \\
\hline & $\begin{array}{l}\text { Adjective + } \\
\text { that-clause }\end{array}$ & 2 & $4 \%$ & \\
\hline Lexical & Verb + noun & 10 & $21 \%$ & $68 \%$ \\
\hline
\end{tabular}




\begin{tabular}{|c|c|c|c|}
\hline Collocation & $\begin{array}{c}\text { Adjective }+ \\
\text { noun }\end{array}$ & 2 & $4 \%$ \\
\cline { 2 - 4 } & $\begin{array}{c}\text { Quantifier + } \\
\text { noun }\end{array}$ & 2 & $4 \%$ \\
\cline { 2 - 4 } & $\begin{array}{c}\text { Adverb + } \\
\text { Adjective }\end{array}$ & 4 & $9 \%$ \\
\cline { 2 - 4 } & Verb + Adverb & 13 & $28 \%$ \\
\hline
\end{tabular}

\section{The Dominant Types of Repetition Used by The Teacher}

The occurrence frequency of collocations varied in each class taught by the same teacher in SMA Negeri 11 Medan. However, the topic brought to the 4 (four) different the classes was recount text, so it was expected that the occurrence frequency of collocation were not supposed to be much different in each class. The following table displays the collocations that occured more than once in the teacher's talk within 4 (four) classes with the topic of recount text.

\begin{tabular}{|l|l|l|l|l|l|}
\hline \multirow{2}{*}{ Collocation } & \multicolumn{3}{|l}{ Frequency Ranges } & \multirow{2}{*}{ Total } \\
\cline { 2 - 5 } Pay attention & 1 time & 7 times & - & 1 time & 9 times \\
\hline Calm down & - & - & 2 times & - & 2 times \\
\hline Have a seat & - & 1 time & 2 times & - & 3 times \\
\hline $\begin{array}{l}\text { Listen } \\
\text { carefully }\end{array}$ & - & 2 times & - & 1 time & 3 times \\
\hline Hurry up & - & 2 times & 2 times & 1 time & 5 times \\
\hline Go on & - & - & 1 time & 1 time & 2 times \\
\hline Did laundry & 4 times & - & - & - & 4 times \\
\hline Come on & 1 time & 2 times & - & 1 time & 3 times \\
\hline Have a look & 1 time & 4 times & 3 times & - & 8 times \\
\hline $\begin{array}{l}\text { Take a photo/ } \\
\text { take photos }\end{array}$ & 4 times & - & & - & 4 times \\
\hline Do homework & - & 1 time & 3 times & 1 time & 5 times \\
\hline
\end{tabular}




\begin{tabular}{|l|l|l|l|l|l|}
\hline Heavy Rain & - & 4 times & - & - & 4 times \\
\hline
\end{tabular}

The collocations of 'pay attention' and 'have a look' were the most frequent collocation that occured in teacher talk. This means, compared to other collocation, 'pay attention' and 'have a look' fit in various different contexts and situations in teaching and learning activity in the classroom.

\section{The Reason of Repetition of Collocation}

The repetition of collocation in 4 (four) parallel classes during the teaching and learning process have different function. The following is the tabular form of the functions of repetition.

\begin{tabular}{|c|c|c|c|c|}
\hline \multicolumn{4}{|c|}{ Functions } & \\
\hline \multicolumn{3}{|c|}{ Classroom Management } & \multirow{2}{*}{$\begin{array}{l}\text { Language } \\
\text { Feature of } \\
\text { Recount text }\end{array}$} & \\
\hline Controlling & Commanding & Encouraging & & \\
\hline Pay attention & Have a seat & \multirow[t]{7}{*}{ Come on } & Did laundry & \multirow{7}{*}{ Collocation } \\
\hline Calm down & Hurry up & & Heavy Rain & \\
\hline \multirow{5}{*}{$\begin{array}{l}\text { Listen } \\
\text { carefully }\end{array}$} & Go on & & \multirow{4}{*}{$\begin{array}{l}\text { Take a photo/ } \\
\text { take photos }\end{array}$} & \\
\hline & Do homework & & & \\
\hline & Have a look & & & \\
\hline & Give a hand & & & \\
\hline & $\begin{array}{l}\text { Give a warm } \\
\text { applause }\end{array}$ & & Shout aloud & \\
\hline
\end{tabular}

The table 4.5 shows that most of the collocations that the teacher repeated in the classroom functioned as a tool for teacher to manage the classroom. The word combination of 'pay attention', 'calm down', listen carefully' and 'have a look' were used by teachers when class conditions were less conducive. By using those phrases, the teacher got the attention of students and managed to settle down the class. While the phrases of 'have a seat', 'hurry up', 'go on', 'come on', and 'do homework' were used by the teacher in conditions where students must do something that the teacher wanted

There were very few of repeated collocations functionated as language feature of recount text. This infers that teacher only tends to repeat the word combinations considered as pedagogical lexemes, no wonder so because it is inseparable from the function of the teacher as a class manager. Meanwhile, the collocations related to learning material were rarely repeated. This shows that teacher actually rarely emphasizes new vocabulary on the students. It is contradictory to the statements of experts which referring to constantly repeat collocations. 


\section{CONCLUSIONS AND SUGGESTIONS}

\section{A. The conclusions}

Within 4 (four) meetings, the teacher carried out the self-repetition $97 \%$ while the other-self repetition only was only carried out $3 \%$. The the other-repetition was done by asking the students repeat the collocation that the teacher said. While the self-repetition was done by the teacher alone trough mentioning the same collocations in a row or once a while.

The collocation in teacher talk is mostly repeated in managing the classroom rather than in learning material. In managing the classroom, the teacher control, command, and encourage the students. While in learning material, the collocation was rarely repeated because text genre did not provide enough opportunities to practice new vocabulary.

\section{B. Suggestions}

In line with conclusions above, some suggestions are recommended as follows:

The students need to be aware of the collocation types and the occurace in teacher talk to lead them to the effectiveness of collocation utilization.

It is recommended to conduct the further research to find out what other collocations that teachers repeat especially on different basic competency and learning materials.

Teachers need to adjust the use of collocation to the results of existing studies to help students in language aquicition. Also the teachers who directly involve in the teaching learning process at school are strongly suggested to salient the collocation by repeating them many times and also recycling them more in many different context and situation in the class. Having the students repeat the collocation is also need to be implemented so support the studeng labguage acqusition.

\section{REFERENCES}


Bogdan, Robert C. dan Biklen Kopp Sari, 1982, Qualitative Research for Education: An Introduction to Theory and Methods. Allyn and Bacon, Inc.: Boston London.

Boers, F., \& Lindstromberg, S. 2008. How cognitive linguistics can foster effective vocabulary teaching. Applications of cognitive linguistics: Cognitive linguistic Approaches to teaching vocabulary and phraseology (pp.1-61). Berlin: Mouton de Gruyter.

Croft, W., \& Cruse, D. 2004. Cognitive Linguistics. Cambridge: Cambridge University Press

Duan, M. and X. Qin. 2012. Collocation in English Teaching and Learning in Theory and Practice in Language Studies. Vol. 2, No. 9: 1890-1894

Hornby, A.S. 1995. Oxford Advanced Learners Dictionary of Current English. London: Oxford University Press.

Larson-Freeman, D. 2000. Techniques and Principles in Language Teaching. Oxford University Press.

Matthews, Peter H. 1981. Syntax. Cambridge: Cambridge University Press.

Norrick, N. 1987. Functions of Repetitions in Conversation. Text 7.3 (1987): 245264

Quirk, Randolph. 1991. English in Use. Addison-Wesley Longman Ltd

Shin, D., \& Nation, P. 2008. Beyond single words: the most frequent collocations in Spoken English. ELT Journal, 62(4), 339-348.

Silva, G. 2007. Framing Participation Through Repetition: The Case of a Portuguese Learner in Different Settings.

Tannen, D. 1987. Repetition in Conversation as Spontaneous Formulaicity. Text 7.3: 215-243.

Xiao-Yan. 2006. A Dissertation Teacher Talk and EFL in University Classrooms. The Asian EFL Journal. 